\title{
Meningkatkan Kemampuan Motorik Halus Anak dengan Pembelajaran Menggambar Menggunakan Program Paint Pada Anak Kelompok A Di TK Negeri Pembina Semarang
}

\author{
Nurfaizah $^{1}$, Herry S. Mangiri ${ }^{2}$ \\ Guru TK Negeri Pembina Semarang 1 Prodi Pendidikan Informatika IKIP Veteran Semarang 2 \\ nurfaizah@gmail.com ${ }^{1}$ ch2mangiri@gmail.com ${ }^{2}$
}

\begin{abstract}
Kemampuan motorik halus selama pembalajaran di PAUD masih mengguanakan cara-cara yang konvensional dan kurang menarik minat siswa untuk belajar. Dengan berkembangnya teknologi maka cara konvesioanl di rubah dengan memanfaatkan media teknologi informasi berupa program Paint dengan peralatan pendukung komputer. Dari hasil penelitian dalam upaya meningkatkan kemampuan motorik halus diperoleh data dalam observasi dan analisa yang telah dilakukan, diperoleh hasil yaitu: Pada kondisi awal diperoleh hasil observasi terhadap aktifitas anak yang belum berkembang sebesar $42,10 \%$ sedangkan yang mulai berkembang sebesar $7,8 \%$, ini menunjukkan bahwa pada kegiatan menggambar kondisi awal belum menunjukkan adanya minat dan daya tarik anak-anak sehingga diperlukan adanya perbaikan untuk dapat memperoleh hasil yang optimal. Perbaikan yang harus dilakukan harus menyeluruh, baik kinerja guru maupun aktifitas anak. Dari hasil perbaikan pada siklus I terhadap penelitian aktifitas anak sebesar 56,6 \% sedangkan pada kinerja guru sebesar 66,6\% dan siklus II pada kinerja guru diperoleh hasil sebesar 85,41 \% dan pada aktifitas anak sebesar $90 \%$ artinya adanya kenaikan sebesar $18,81 \%$ dari siklus I dan siklus II yang menunjukkan bahwa pembelajaran menggambar dengan menggunakan program paint diperoleh hasil yang signifikan dan dapat dinyatakan berhasil dengan baik.
\end{abstract}

Kata Kunci: menggambar, program Paint, motorik halus.

Fine motor skills during pembalajaran in early childhood are still ways that conventional and less attractive students to learn. With the development of technology, the conventional means $d$ by the media using information technology such as the Paint program with computer support equipment.

From the research in an effort to improve fine motor skills acquired data in the observation and analysis has been done, the result is: In the initial condition is obtained on the observation of the activities of children who have to grow at $42.10 \%$ while that began to grow by $7.8 \%$, this shows that in drawing the initial condition has not shown any interest and appeal of children so that the necessary improvements in order to obtain optimal results. Improvements to be made to be thorough, good performance of teachers and child activities. The repairs on the first cycle of the research activities of children by $56.6 \%$ while in the performance of teachers by $66.6 \%$ and the second cycle the teacher performance obtained yield was $85.41 \%$ and the child's activities by $90 \%$ means an increase of $18,81 \%$ of the first cycle and the second cycle which indicates that learning to draw using a paint program obtained significant results and can be declared successful.

Keywords: draw, paint Program, fine motor. 


\section{PENDAHULUAN}

Pada era globalisasi ini, komputer merupakan suatu peralatan yang sangat dibutuhkan oleh masyarakat luas dan tidak terbatas pada kalangan tertentu saja. Begitu besarnya manfaat yang dapat diperoleh dengan penggunaan teknologi komputer maka kitapun harus siap menghadapi kemajuan era globalisasi ini.

Perkembangan komputer yang semakin pesat menuntut anak didik kita untuk mempelajarinya sejak dini dengan harapan semoga mereka kelak bisa menjadi sumber daya manusia yang handal di masa yang akan datang.

Usia dini atau lebih dikenal dengan usia Golden Age adalah masa emas dimana usia itu tak akan dapat terulang lagi. Pada masa ini anak sangat peka dalam memperoleh rangsangan, baik yang berkaitan dengan aspek fisik motorik, intelektual, sosial emosional ataupun bahasa. Peran guru, orang tua dan lingkungan sangat dibutuhkan dalam mengembangkan dan mengoptimalkan kemampuan tumbuh kembang anak. Stimulus-stimulus yang sesuai kebutuhan pada anak akan memberikan hasil yang optimal. Pertumbuhan dan perkembangan anak dapat dilihat dari tahapan yang telah dicapai anak tersebut. Masa kritis pada anak adalah faktor utamanya, untuk itu perlu adanya pengawasan pada anak dalam memberikan kegiatan untuk menstimulusnya.

Menggambar bagi anak-anak merupakan salah satu kegiatan bermain, yang dilakukan dalam rangka memberikan kesenangan, kepuasan ekspresi, eksplorasi dan unjuk kebolehan. Dalam kegiatan menggambar ini banyak manfaat yang akan diperoleh, diantaranya mengembangkan ketrampilan motorik halus, mengembangkan imajinasi, kreativitas, memanfaatkan waktu luang, melatih ketelitian dan ketekunan, melatih dan mengembangkan konsentrasi hingga memantapkan bakat anak.

Menurut Sudjani, ( 1996 : 54 ) Seni menggambar di TK merupakan kegiatan yang kaya akan fantasi dan kreasi. Pada masa ini kreasi anak memiliki ciri khas yang sangat unik dan orisinil. Berangkat dari keunikan inilah sentuhan tangan-tangan trampil dari seorang pendidik diperlukan dengan jalan mengenalkan berbagai media / teknik yang didasari dengan kedisiplinan dan tanggung jawab. Pada masa ini anak diharapkan bebas dan lepas untuk berekspresi agar bisa mengungkapkan citra diri serta potensinya yang mungkin tersembunyi.

Seiring dengan perkembangan zaman, penulis juga merasa harus belajar untuk menggunakan teknologi informasi dalam kegiatan pembelajaran. Peralatan teknolog informasi yang di pergunakan adalah Komputer. Dengan media komputer dan memanfaatkan program Microsoft office yang telah ada yaitu program Paint untuk menggambar membuat ketertarikan anak-anak untuk mencoba dan menggunakannya.

Secara konseptual, pendidikan seni di Taman Kanak-kanak diarahkan pada perolehan atau kompetensi hasil belajar yang beraspek pengetahuan dan ketrampilan. Pengembangan kemampuan dasar merupakan kegiatan yang dipersiapkan guru untuk meningkatkan kreativitas sesuai dengan tahap perkembangan anak yang salah satunya adalah bidang fisik motorik baik motorik kasar maupun motorik halus. Pengembangan ini bertujuan untuk memperkenalkan dan melatih gerakan motorik anak, meningkatkan kemampuan mengelola, mengontrol gerakan tubuh dan koordinasi mata dan tangan.

Ketertarikan anak-anak dalam menggunakan media komputer dengan menggunakan program Paint ini dapat di manfaatkan oleh para guru untuk melatih motorik halus anak.

\section{KAJIAN TEORI}

\section{Kemampuan Motorik Halus}

Menurut Sumantri, ( 2005 ; 143 ) Pengertian motorik halus merupakan pengorganisasian penggunaan otot-otot kecil seperti jari jemari dan tangan yang sering membutuhkan 
kecermatan dan koordinasi mata dan tangan, ketrampilan yang mencakup pemanfaatan dengan alat-alat untuk bekerja dan obyek yang kecil / pengontrolan terhadap mesin.

Tujuan dari pengembangan motorik halus anak menurut Sumantri, ( $2005 ; 146$ ) antara lain adalah: anak mampu mengembangkan motorik halus yang berhubungan dengan ketrampilan gerak kedua tangan; anak mampu menggerakan anggota tubuh yang berhubungan dengan gerak jemari. Seperti kesiapan menulis, menggambar dan memanipulasi benda-benda; mampu mengkoodinasikan indera mata dan aktivitas tangan; menunjukkan kemampuan menggerakan anggota tubuh dan terutama terjadi koordinasi antara mata dan tangan.

Saat ini kemajuan dibidang komputer telah meluas hingga ke dunia sekolah. Dunia komputer saat ini telah memperkenalkan sedini mungkin tentang kemampuan, bakat dan potensi dunia anak dalam berkarya dan berilustrasi menggunakan komputer.

Program paint dirancang untuk menggantikan kertas, pensil, pensil warna, cat air ataupun krayon untuk aktifitas menggambar. Dengan menggunakan program ini orang tidak akan kehabisan bahan untuk menggambar dan tidak mengotori baju ataupun tangan. Pengguna dapat menggambar apa saja, baik pemandangan ataupun yang bersifat abstrak.

\section{Program Paint}

Komputer merupakan suatu sistem yang didalamnya terdapat perangkat lunak (software). Perangkat lunak terbagi menjadi dua bagian yaitu perangkat lunak Operating System (OS) dan perangkat lunak program aplikasi. Software (perangkat lunak) adalah program agar komputer dapat melakukan tugas-tugas tertentu yang diharapkan pemakai. Contoh : menggambar. Program Paint merupakan salah satu salah satu program yang digunakan untuk membuat dan mengedit / memperbaiki gambar. Program paint sangat mudah dipelajari. Kelebihan yang dimiliki program paint, yaitu sebagai berikut: 1) mudah dipelajari sehingga mudah pula untuk di pergunakan; 2) telah tersedia di dalam sistem operasi Windows, 3) tidak banyak memakan ruang harddisk, 4) dapat membuat wallpaper ( latar belakang desktop) secara otomatis.

Aplikasi paint merupakan salah satu program pada komputer yang dapat digunakan untuk proses gambar menggambar. Paint sangat mudah digunakan dan dapat dikuasai dengan cepat selain itu hasil gambar dapat dicetak/diprint. Windows dilengkapi dengan program menggambar yang terpasang, disebut paint.

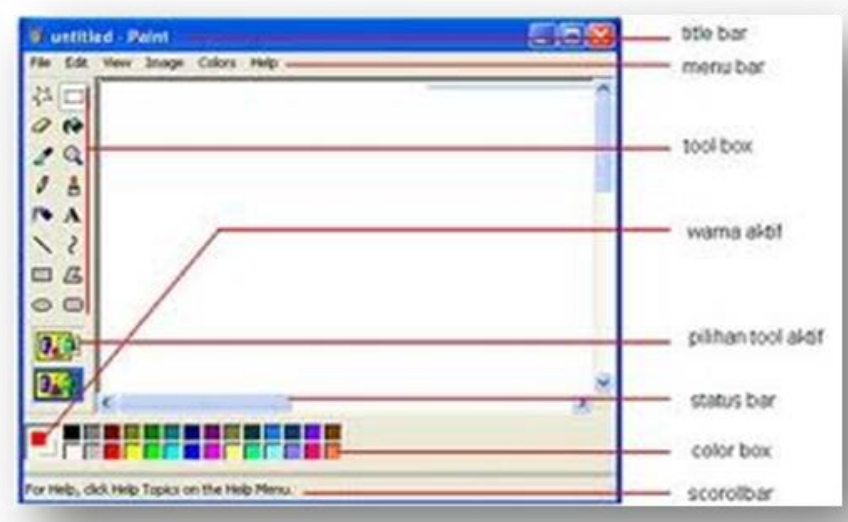

Gambar 1. Tampilan Program Paint 


\section{METODE}

Penelitian Tindakan kelas merupakan terjemahan dari Classroom Action Research, yaitu satu penelitian yang mempunyai aturan dan langkah yang harus diikuti, yang oleh Carr \& Kemmis ( McNiff, 1991, p.2 ) didefinisikan sebagai berikut : 1) penelitian tindakan adalah satu bentuk inkuiri atau penyelidikan yang dilakukan melalui refleksi diri, 2) penelitian tindakan dilakukan oleh peserta yang terlibat dalam situasi yang diteliti, seperti guru, anak atau kepala sekolah, 3) penelitian tindakan dilakukan dalam situasi sosial, termasuk situasi pendidikan, 4) tujuan penelitian tindakan adalah memperbaiki: dasar pemikiran dan kepantasan dari praktik-praktik, pemahaman terhadap praktik tersebut, serta situasi atau lembaga tempat praktik tersebut dilaksanakan.

Penelitian tindakan kelas adalah penelitian yang dilakukan oleh guru dikelasnya sendiri melalui refleksi diri dengan tujuan untuk memperbaiki kinerjanya sehingga hasil belajar siswa meningkat.

Menurut argumentasi yang dikemukakan (Hopkins, 1993, hal. 34-42) pertama, guru yang baik perlu mempunyai otonomi dalam melakukan penilaian profesional, dan mengetahui apa yang harus dikerjakan. Kedua, ketidaktepatan paradigma penelitian tradisional dalam membantu guru memperbaiki kinerjanya dalam mengajar.

Pada metode penelitian ini menggunakan teknik observasi atau pengamatan dan interpretative yaitu menginterpretasikan data mengenai fenomena / gejala yang diteliti di lapangan. Untuk subyek penelitian adalah Subyek penelitian ini adalah ; 1) anak-anak kelompok A di TK Negeri Pembina Demak Tahun Ajaran 2013-2014, 2) pendidik di TK Negeri Pembina Mranggen Demak dan 3) pimpinan TK Negeri Pembina Mranggen Demak. Sedang instrument penelitian adalah ; 1) observasi, yaitu melihat fenomena yang menarik untuk dijadikan fokus penelitian. 2) wawancara, yaitu untuk menggali informasi lebih mendalam mengenai fokus penelitian dan 3) dokumentasi, yaitu untuk mengumpulkan bukti-bukti dan penjelasan yang lebih baik mengenai fokus penelitian.

\section{HASIL PENELITIAN}

Pelaksanaan tindakan perbaikan pada siklus I ini dimulai dan dibantu oleh bapak danang selaku observer. Pada pelaksanaan tindakan perbaikan, dilakukan dalam beberapa tahap yaitu sebagai berikut :

\section{Perencanaan}

Langkah-langkah pada perencanaan yaitu: 1) berkolaborasi dengan observer mengenai tindakan kelas yang akan diambil, 2) menyiapkan lembar observasi kinerja guru, lembar aktifitas menggambar anak dan lembar evaluasi kemampuan anak, 3) mempersiapkan RKH yang akan dilaksanakan.

\section{Pengamatan}

Pengamatan memperlihatkan kegiatan guru membuka pelajaran dengan menyapa anak, dilanjutkan dengan berdoa, absen, kalender dan bernyanyi. Kemudian guru memberikan penjelasan menggambar sesuai tema. Anak-anak mempersiapkan meja lipat, buku gambar, krayon dan spidol hitam besar. Guru memberikan contoh cara menggambar selangkah demi selangkah dan anak-anak menirukannya. Anak-anak merapikan paralatan menggambarnya. Mengulas dan tanya jawab tentang apa yang digambar anak-anak dan cara/urutan menggambarnya. Berdoa bersama-sama dan salam.

Selama kegiatan pembelajaran menggambar berlangsung dilakukan pengisian lembar pengamatan guru dan anak yang diisi oleh observer, dan pengamatan kemampuan hasil belajar anak yang dilakukan oleh peneliti untuk pengumpulan data penelitian selama siklus 1 . 
Observasi

Didalam observasi pada siklus I diperoleh hasil dari pengamatan kinerja guru, penilaian hasil menggambar anak dan skoring yang penggambaran dari hasil penelitian melalui pengolahan data dalam bentuk tabulasi penilaian kinerja guru, penilaian aktivitas siswa dan kemampuan siswa dan digambarkan pula dalam bentuk grafik. Berdasarkan observasi dan skoring selama pelaksanaan tindakan perbaikan siklus I yang tercantum dalam lampiran penelitian diketahui hasil pengamatan kinerja guru selama siklus 1 dalam tabel berikut :

Tabel 1. Hasil observasi kegiatan menggambar anak pada siklus I

\begin{tabular}{|c|c|c|c|c|}
\hline \multirow{3}{*}{ No } & \multirow{3}{*}{ Aspek Yang Diamati } & \multicolumn{3}{|c|}{ Skor } \\
\hline & & Baik & Cukup & Kurang \\
\hline & & 3 & 2 & 1 \\
\hline 1 & Antusias anak dalam kegiatan belajar & $\sqrt{ }$ & & \\
\hline 2 & Sikap anak dalam menerima motivasi guru & & & $\sqrt{ }$ \\
\hline 3 & Respon anak dalam kegiatan apersepsi & & $\sqrt{ }$ & \\
\hline 4 & Perhatian anak mendengarkan penjelasan guru & & $\sqrt{ }$ & \\
\hline 5 & 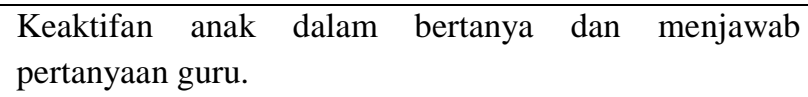 & & & $\sqrt{ }$ \\
\hline 6 & $\begin{array}{l}\text { Partisipasi anak menirukan materi dan mengkreasikan } \\
\text { sesuai dengan kemampuan yang dimilikinya. }\end{array}$ & & & $\sqrt{ }$ \\
\hline 7 & Partisipasi anak dalam kegiatan menggambar. & & $\sqrt{ }$ & \\
\hline 8 & Keaktifan anak dalam menarik kesimpulan hasil belajar. & & $\sqrt{ }$ & \\
\hline 9 & Respon anak mengerjakan tugas dari guru. & & & $\sqrt{ }$ \\
\hline 10 & Kemampuan anak berinteraksi dengan teman lainnya. & & $\sqrt{ }$ & \\
\hline \multicolumn{2}{|c|}{ Total skor } & 1 & 5 & 4 \\
\hline \multicolumn{2}{|c|}{ Total skor max $=$ jumlah indikator $\mathrm{x} 3$} & 30 & & \\
\hline \multicolumn{2}{|c|}{ Persentase skor $=\left(\frac{\text { total skor }}{30} \times 100 \%\right.$} & $56,6 \%$ & & \\
\hline \multicolumn{2}{|c|}{$\begin{array}{l}26 \%<X \leq 50 \%=2 ; 51 \%<X \leq 75 \%=3 \\
76 \%<X \leq 100 \%=4)\end{array}$} & 3 & & \\
\hline
\end{tabular}

Berdasarkan hasil tabulasi diatas selama pelaksanaan kegiatan menggambar diperoleh hasil persentase 56,6 \% yang artinya seluruh aspek yang diamati belum menunjukkan hasil yang optimal sehingga perlu adanya perbaikan pada siklus II. Untuk memperjelas hasilnya dapat dilihat pada grafik dibawah ini : 


\section{Penilaian Siswa setelah Siklus I}

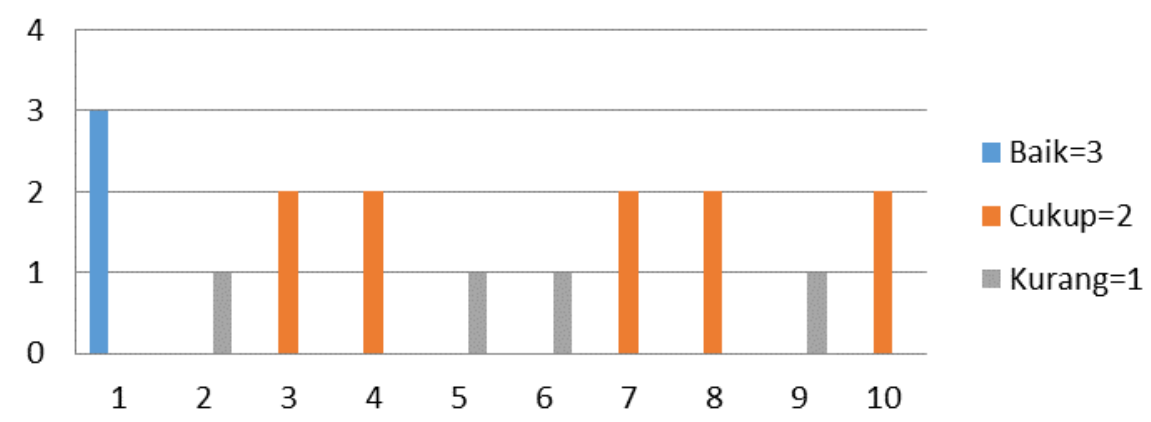

Gambar 2. Grafik Aktifitas kegiatan pembelajaran menggambar anak pada siklus I

Pada pelaksanaan kegiatan menggambar pada aspek yang diamati yang persentasenya tertinggi yaitu pada antusias anak-anak dalam belajar, sedangkan aspek-aspek yang lain masih banyak yang perlu diperbaiki. Selain data tabulasi diatas dapat dilihat pula dokumentasi pembelajaran pada siklus I ini, yaitu sebagai berikut

Tabel 2. Penilaian kegiatan menggambar dengan menggunakan program paint Siklus II

\begin{tabular}{|c|c|c|c|c|}
\hline \multirow{3}{*}{ No } & \multirow{3}{*}{ Aspek Yang Diamati } & \multicolumn{3}{|c|}{ Skor } \\
\hline & & Baik & Cukup & Kurang \\
\hline & & 3 & 2 & 1 \\
\hline 1 & $\begin{array}{l}\text { Antusias anak dalam kegiatan menggambar dengan } \\
\text { menggunakan program paint }\end{array}$ & $\sqrt{ }$ & & \\
\hline 2 & Sikap anak dalam menerima motivasi guru & $\sqrt{ }$ & & \\
\hline 3 & Respon anak dalam kegiatan apersepsi & & $\sqrt{ }$ & \\
\hline 4 & Perhatian anak dalam mendengarkan penjelasan guru & $\sqrt{ }$ & & \\
\hline 5 & $\begin{array}{l}\text { Keaktifan anak dalam bertanya dan menjawab } \\
\text { pertanyaan guru. }\end{array}$ & $\sqrt{ }$ & & \\
\hline 6 & $\begin{array}{l}\text { Ketertarikan anak pada kegiatan menggambar dengan } \\
\text { menggunakan program paint }\end{array}$ & $\sqrt{ }$ & & \\
\hline 7 & $\begin{array}{l}\text { Partisipasi anak menirukan cara menggambar dengan } \\
\text { menggunakan program paint }\end{array}$ & $\sqrt{ }$ & & \\
\hline 8 & Kemampuan anak berinteraksi dengan teman lainnya. & & $\sqrt{ }$ & \\
\hline 9 & Respon anak mengerjakan tugas dari guru. & $\sqrt{ }$ & & \\
\hline 10 & $\begin{array}{l}\text { Keaktifan anak dalam menarik kesimpulan hasil } \\
\text { belajar. }\end{array}$ & & $\sqrt{ }$ & \\
\hline \multicolumn{2}{|c|}{ Total skor } & $\begin{array}{l}7 \times 3=2 \\
1\end{array}$ & $3 \times 2=6$ & $0 \times 1=0$ \\
\hline \multicolumn{2}{|c|}{ Total skor $\max =$ jumlah indikator $\mathrm{x} 3$} & 30 & & \\
\hline \multicolumn{2}{|c|}{ Persentase skor $=\left(\frac{\text { total skor }}{30}\right) \times 100 \%$} & $90 \%$ & & \\
\hline \multicolumn{2}{|c|}{ Nilai untuk kegiatan akhir $=(0 \%<X \leq 25 \%=1$} & 4 & & \\
\hline
\end{tabular}




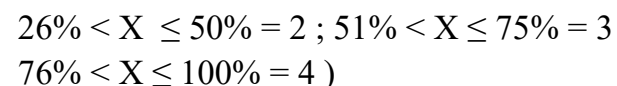

Dari hasil penilaian diatas dapat kita lihat adanya perkembangan di pelaksanaan kegiatan menggambar dengan menggunakan program paint pada siklus II ini yaitu adanya kenaikan dari 56,6 $\%$ menjadi $90 \%$ yang berarti mengalami kenaikan adanya keberhasilan 33,4 \%, artinya terjadi kenaikan yang signifikan. Penggambaran hasil penilaian pada kegiatan menggambar dalam penelitian dapat dilihat pula dalam bentuk grafik seperti dibawah ini :

\section{Penilaian siswa setelah siklus II}

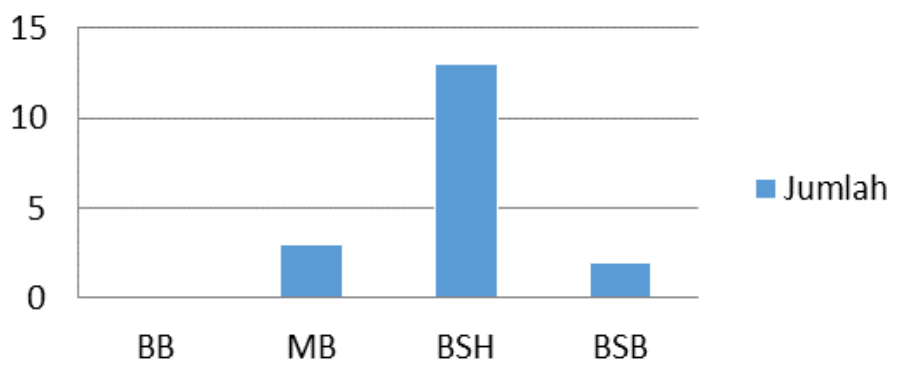

Gambar 3.Grafik penilaian menggambar dengan menggunakan program paint

\section{DISKUSI}

Berdasarkan observasi terhadap kemampuan siswa dengan berdasarkan indikator kemampuan melakukan kegiatan menggambar yaitu menggunakan program paint sesudah pelaksanaan tindakan perbaikan pembelajaran siklus II diketahui bahwa kemampuan siswa siswa di Kelompok A di TK Negeri Pembina Semarang menunjukkan jumlah terbesar pada kategori Baik sebanyak 7 siswa atau sebesar 90\%, sementara siswa yang masuk dalam kategori kurang tidak ada atau 0\%. Hal tersebut menunjukkan peningkatan yang cukup pesat dibandingkan dengan hasil siklus I ke siklus II di mana terdapat pertambahan jumlah siswa yang meningkat kategori kemampuannya. Hal ini menunjukkan keberhasilan pencapaian persentase keberhasilan hingga melebihi $85 \%$.

Tabel 3. Perbandingan Kinerja Guru Siklus 1 dan Siklus 2

\begin{tabular}{lllll} 
No & Aspek yang diamati & Siklus I & Siklus II & Keterangan \\
\hline 1 & Pendahuluan & $55,5 \%$ & $100 \%$ & Naik \\
\hline 2 & Kegiatan Inti & $60 \%$ & $80 \%$ & Naik \\
\hline 3 & Kegiatan Akhir & $55,5 \%$ & $88,8 \%$ & Naik \\
\hline Rata-rata & $66,6 \%$ & $85,41 \%$ & Naik
\end{tabular}

Tabel 4. Perbandingan Aktivitas Anak pada Siklus 1 dan Siklus 2

\begin{tabular}{lll} 
No & Aspek yang diamati & Aspek yang diamati \\
\hline 1 & Antusias anak dalam kegiatan menggambar & $\begin{array}{l}\text { Antusias anak dalam kegiatan menggambar } \\
\text { dengan menggunakan program paint }\end{array}$ \\
\hline 2 & Sikap anak dalam menerima motivasi guru & Sikap anak dalam menerima motivasi guru
\end{tabular}




\begin{tabular}{llll}
3 & Respon anak dalam kegiatan apersepsi & Respon anak dalam kegiatan apersepsi \\
\hline 4 & $\begin{array}{l}\text { Perhatian anak mendengarkan penjelasan } \\
\text { guru }\end{array}$ & $\begin{array}{l}\text { Perhatian anak dalam mendengarkan } \\
\text { penjelasan guru }\end{array}$ \\
\hline 5 & $\begin{array}{l}\text { Keaktifan anak dalam bertanya dan } \\
\text { menjawab pertanyaan guru. }\end{array}$ & $\begin{array}{l}\text { Keaktifan anak dalam bertanya dan menjawab } \\
\text { pertanyaan guru. }\end{array}$ \\
\hline 6 & $\begin{array}{l}\text { Partisipasi anak menirukan materi dan } \\
\text { mengkreasikan sesuai dengan kemampuan } \\
\text { yang dimilikinya. }\end{array}$ & $\begin{array}{l}\text { Partisipasi anak menirukan cara menggambar } \\
\text { dengan menggunakan program paint }\end{array}$ \\
\hline 7 & $\begin{array}{l}\text { Partisipasi anak dalam kegiatan } \\
\text { menggambar. }\end{array}$ & $\begin{array}{l}\text { Ketertarikan anak pada kegiatan menggambar } \\
\text { dengan menggunakan program paint }\end{array}$ \\
\hline 8 & $\begin{array}{l}\text { Kemampuan anak berinteraksi dengan } \\
\text { teman lainnya. }\end{array}$ & $\begin{array}{l}\text { Kemampuan anak berinteraksi dengan teman } \\
\text { lainnya. }\end{array}$ \\
\hline 9 & $\begin{array}{l}\text { Respon anak mengerjakan tugas dari guru. } \\
\text { Respon anak mengerjakan tugas dari guru. }\end{array}$ \\
\hline 10 & $\begin{array}{l}\text { Keaktifan anak dalam menarik kesimpulan } \\
\text { hasil belajar. }\end{array}$ & $\begin{array}{l}\text { Keaktifan anak dalam menarik kesimpulan } \\
\text { hasil belajar. }\end{array}$ \\
\hline Siklus I $=56,6 \%$ & Siklus II = 90 \% \\
\hline Siklus II - Siklus I = 33,4\% & & \\
\hline
\end{tabular}

Sedangkan rekapitulasi hasil peningkatan dari observasi awal ke siklus I dan siklus II menunjukkan bahwa seluruh indikator menunjukkan peningkatan yang terlihat pada grafik di bawah.

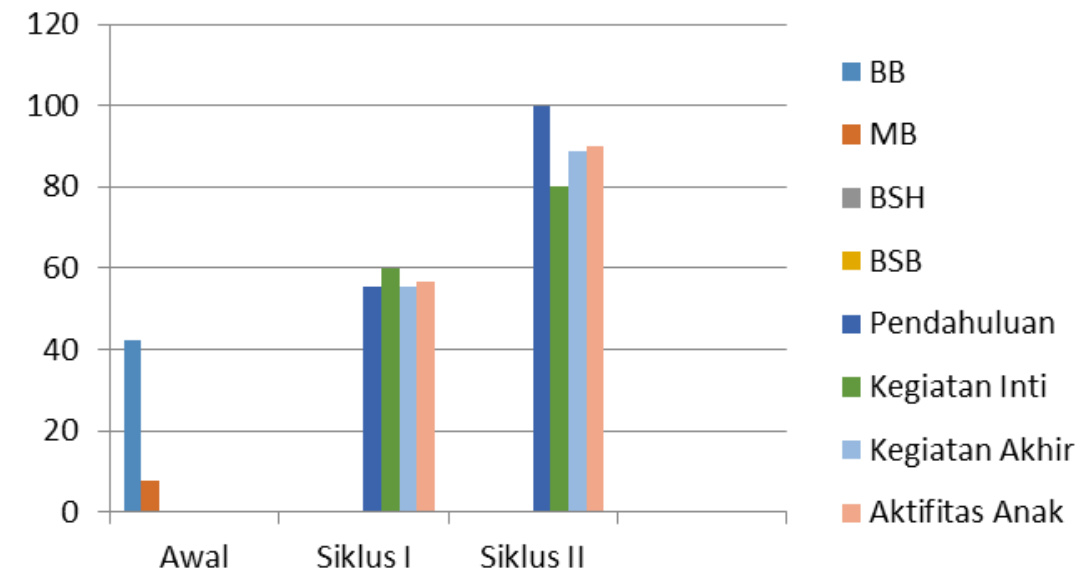

Gambar 4. Perbandingan hasil penilaian dari awal pembelajaran samapi siklus II

\section{KESIMPULAN}

Dari tabulasi dan analisis data dapat disimpulkan bahwa Kegiatan pembelajaran menggambar menggunakan program paint ini dapat meningkatkan motorik halus anak-anak terutama dalam hal membuat garis vertikal, horisontal, miring, lengkung dan lingkaran, melatih koordinasi mata dan tangan serta mampu meningkatkan kemampuan anak dalam melakukan gerakan manipulatif yang menghasilkan suatu hasil didalam menggunakan media komputer.

Sedangkan saran dan rekomendasi antara lain: 1) dalam meningkatkan kemampuan menggambar anak dalam menggunakan program paint sebaiknya anak perlu banyak latihan dan diberikan keluasan dalam berkreasi dan berimajinasi; 2) anak tidak boleh menghidupkan dan mematikan Perangkat 
Komputer itu sendiri dan pada awal pembelajaran komputer, program paint telah siap di gunakan untu menggambar oleh anak-anak.

\section{REFERENSI}

Abdul Kodir, 2011. Having Fun with Computers !. Yogyakarta: CV Andi Offset.

Andriyanti, 2003. Mahir Komputer untuk Anak Cerdas. Bandung: Titian Ilmu (Anggota Ikapi).

Benny A. Pribadi, dkk, 2008. Komputer dalam Kegiatan Pengembangan Anak Usia Dini. Jakarta. Universitas Terbuka.

Christine Wibhowo dan Ridwan Sanjaya, 2011. Stimulasi Kecerdasan Anak Menggunakan Teknologi Informatika. Jakarta: PT Elex Media Komputindo.

Donny Aprilianto, 2009. Menggambar Asyik Pakai Microsoft Paint untuk Anak. Yogyakarta: Pustaka Anggrek, cetakan I.

Hopkins, David, 1993. A Teacher`s Guide to classroom Research. Philadelphia : Open University Press.

IGAK Wardhani, Kuswaya Wihardit, 2008. Penelitian Tindakan Kelas. Edisi I Jakarta : Universitas Terbuka.

Kemmis, s. \& Mc Taggart. R, (1983) The Action Research Planner. $3^{\text {rd }}$ ed. Victoria, Australia: Deakin University.

Nursery. I. T, 2002. Whizkids Computer Literacy Program, Philippine: Rex Book Store. Inc.

Rusdarmawan, 2009. Children's Drawing dalam PAUD. Bantul: Kreasi Wacana.

Rusman, 2012. Belajar dan Pembelajaran Berbasis Komputer. Bandung: Alfabeta.

Sanyo Saputra, 2007. Menggambar dengan Microsoft Paint. Jakarta : Ganeca Exact.

Tutang, MM.2008.Belajar Komputer Sejak Dini.” Komputer Bagi Anak-anak”. Jakarta. D@takomlintas Buana.

W. E Kristiono. Menggambar Untuk Anak-anak. CV DANART.

Woro Vidya Ayuningtyas. 2008. Berkenalan dengan Pengolah Gambar. Yogyakarta: CV Andi Off set. 